\title{
Morphological variations of the three otoliths of some species of the family Loricariidae (Ostariophysi: Siluriformes)
}

\author{
Roberto Omar Sánchez ${ }^{1}$ and Virginia Haydee Martínez ${ }^{1,2}$
}

Otoliths are three pairs of calcareous structures found in the inner ear of bony fish. In many cases they display a speciesspecific morphology. The present study describes morphological variations of otoliths, namely lapillus, asteriscus and sagitta, of eleven-species belonging to four loricariid subfamilies. Otolith structures that characterize the Loricariidae and some of its subfamilies are presented. The sagitta exhibit a specific morphology that is not found in other siluriform families; it is claviform with a tapered posterior region and a flared anterior one. In the latter, central elevations are observed and the dorsal wings are continuous with lateral expansions named basal wings. Hypoptopomatinae and Loricariinae as well as Hypostominae and Ancistrinae can be grouped by two morphological patterns of the lapillus: An ovoid pattern, in which the lapillae are elongated in its supero-inferior axis and the mond hardly exceed the anterior edge of the otolith and, an oval pattern, where the lapillae are elongated in their antero-posterior axis and the mond always exceeds the anterior edge in an obvious way. The patterns proposed here could be diagnostic of certain subfamilies.

Keywords: Armored catfishes, Asteriscus, Lapillus, Morphology, Sagitta.

Los otolitos son tres pares de estructuras calcáreas que se encuentran en el oído interno de los peces óseos. En muchos casos ellos muestran una morfología específica para cada especie. El presente estudio describe las variaciones morfológicas de los otolitos, lapillus, asteriscus y sagitta, de once especies pertenecientes a cuatro subfamilias de loricáridos. Se presentan estructuras que caracterizan los otolitos de Loricariidae y a algunas de sus subfamilias. El sagitta exhibe una morfología específica que no se encuentra en otras familias siluriformes: es claviforme con una región posterior cónica y una anterior ensanchada. En esta última, se observan elevaciones centrales; las alas dorsales que se continuan con expansiones laterales denominadas alas basales. Hypoptopomatinae y Loricariinae, así como las subfamilias Hypostominae y Ancistrinae se pueden agrupar por dos patrones morfológicos de la lapillus: Un patrón de forma ovoide, en el que los lapillae son alargados en su eje superior-inferior y el mond difícilmente sobrepasa el borde anterior de los otolitos. El otro es un patrón oval, donde los lapillae son alargados en su eje antero-posterior y el mond siempre sobrepasa el borde anterior de una manera notoria. Los patrones propuestos aquí podrían ser diagnósticos de ciertas subfamilias.

Palabras Clave: Asteriscus, Bagres blindados, Lapilus, Morfologia, Sagitta.

\section{Introduction}

Otoliths are structures found in the inner ear of bony fishes associated with hearing and balance functions (Popper, Lu, 2000). They consist mainly of calcium carbonate crystals like aragonite or calcium phosphate deposited as calcite. They are embedded in a protein matrix named otolina. Fish have three pairs of otoliths on either side of the brain: lapillus, asteriscus and sagitta, placed in three membrane vesicles, utricle, lagena and saccule, called otolith organs, (e.g., Schulz-Mirbach, Reichenbacher, 2006).
Because of their species-specific morphology, otoliths are considered to be taxonomic characters (Adams, 1940). They can be a useful morphological tool for species identification in situations where other methods fail (e.g., Hernández García et al., 2004; Tuset et al., 2012). In addition to their traditional use in taxonomy, they have been used in studies on diet of piscivore predators (e.g., Pierce et al., 1991; Tollit et al., 1997), analysis of allometrics (e.g., Aguirre, 2003; Monteiro et al., 2005), ecomorphology (e.g., Volpedo, Echeverria, 2003; Volpedo, Fuchs, 2010), paleontology (e.g., Nolf, Brzobohatý, 2009), age determination (e.g., Ilkyaz et al., 2011), daily and

${ }^{1}$ Instituto de Bio y Geociencias del Noroeste Argentino (IBIGEO), CONICET-Universidad Nacional de Salta, CCT-Salta, Av. 9 de julio 14 , 4405, Rosario de Lerma, Salta, Argentina. rosanchez333@gmail.com (corresponding author)

${ }^{2}$ Laboratorio de Histología Animal, Facultad de Ciencias Naturales, Universidad Nacional de Salta, Av. Bolivia 5150, 4400, Salta, Argentina. virginia@unsa.edu.ar 
annual growth (e.g., Fowler, 1990; Morales-Nin, 2000), physiological studies (e.g., Popper et al., 2005), analysis of chemical composition (e.g., Campana, 1999; Albuquerque et al., 2010), microstructure (e.g., Correia et al., 2003) and as indicators to detect changes in the habitat conditions (e.g., Volk et al., 1999). In the last decade, several studies have shown that otoliths provide a clear phylogenetic signal and some of their morphological characteristics were used in phylogenetic studies (e.g., Lombarte et al., 2010).

Siluriform otoliths have been studied by several authors. For example: Adams (1940) described otoliths of American Ostariophysi. Tilak (1963) conducted a comparative morphological description of catfish otoliths of India. Mollo (1981) studied the otoliths of siluriforms of the Chascomús lagoon in Argentina. Martínez, Gonzo $(1988,1991)$ studied otoliths of seventeen species of the families Doradidae, Pimelodidae, Trichomycteridae, Callichthyidae, and Loricariidae of the Bermejo and Juramento river basins in the Argentine Northwest. More recently, Fuchs, Volpedo (2009) and Volpedo, Fuchs (2010) described the morphology and morphometric patterns of the lapillus otoliths of 19 siluriforms species belonging to the families: Auchenipteridae, Callichthyidae, Doradidae, Heptapteridae, Loricariidae and Pimelodidae in the Rio de la Plata Basin.

Loricariidae are a diversified family including species distributed in the Neotropical Region. The species have been usually divided into historically unstable subfamilies. Considering the taxonomic use of otoliths, we aim to describe the otolith morphological variations of eleven species belonging to four subfamilies. Morphologies were analyzed in search of characters that may distinguish taxonomic levels

\section{Materials and methods}

We studied forty-five specimens of eleven species representing four loricariid subfamilies. Samples were obtained from direct capture, commercial aquariums, and scientific collections. In all cases the specimens were fixed in formaldehyde solution after overdose with benzocaine. After 48 hours they were transferred to ethanol $(70 \% \mathrm{v} / \mathrm{v})$. The study was conducted in accordance with international standards on animal welfare, and fulfills the criteria established by national regulations from the "Comité Nacional de Ética en la Ciencia y la Tecnología" (National Ethics Committee, Argentina). Otoliths were extracted from all the specimens and their morphology was compared intraspecifically to rule out gross variations, only otoliths obtained from larger adult specimens were selected for the descriptions

To extract the otoliths, the supraoccipital and frontal bones were dissected. The brain was removed under stereo microscope, exposing the inner ear. Subsequently, the otolith organs of the right side were extracted, obtaining the vesicles and corresponding otoliths.
Otoliths were treated for 30 minutes with a solution of $2 \%$ potassium hydroxide in order to remove traces of the vesicle's membranes (Tilak, 1963). Subsequently, they were rinsed with distilled water and stored in glycerin. For analysis, otoliths were observed under a stereo microscope and their outlines were drawn using a camera lucida. To characterize the morphology of the otoliths, we took into account the shape, size and the structure of the surface which holds the morphological characters (ventral face), following the terminology proposed by Adams (1940), Tilak (1963), Martínez, Gonzo (1991), and Assis (2003, 2005).

The material examined was deposited in theichthyological collection of the Instituto de Bio y Geociencias del NOA (IBIGEO - CONICET) under the acronym IBIGEO-I. Also we analyzed material of the ichthyological collection of the Fundación de Historia Natural Félix de Azara. Universidad Maimónides under the acronym IC.

Ancistrus cirrhosus (Valenciennes, 1836): IBIGEO-I 338, 1, $67.13 \mathrm{~mm}$ SL, aquarium specimen, Argentina. Ancistrus sp.: IC10-321, 1, 108.85 mm LS, Uruzu River, Misiones, Argentina. Hypoptopoma inexspectatum (Holmberg, 1893): IBIGEO-I 346, 1, $56.6 \mathrm{~mm}$ SL, aquarium specimen, Argentina. Hypostomus commersoni Valenciennes, 1836: IBIGEO-I 341, 1, $109.12 \mathrm{~mm}$ SL, aquarium specimen, Argentina. Hypostomus paranensis Weyenbergh, 1877: IBIGEO-I 313, 1, 216.66 mm SL, río Arenales, Salta, Argentina. Rineloricaria steinbachi (Regan, 1906): IBIGEO-I 318, 1, 110.4 mm SL, río Arenales, Salta, Argentina. Otocinclus vittatus Regan, 1904: IBIGEO-I 328, 1, $29.14 \mathrm{~mm} \mathrm{SL}$, aquarium specimen, Argentina. Paraloricaria vetula (Valenciennes, 1835): IC10-360, 1, 330.88 mm SL, río Paraná, Buenos Aires, Argentina. Pterygoplichthys anisitsi Eigenmann \& Kennedy, 1903: IBIGEO-I 348, 1, $383.61 \mathrm{~mm} \mathrm{SL}$, río Bermejo, Salta, Argentina. Rineloricaria catamarcensis (Berg, 1895): IBIGEO-I 344, 1, $117.7 \mathrm{~mm}$ SL, río Arenales, Salta, Argentina. Rineloricaria sp.: IBIGEO-I 339, 1, $121.29 \mathrm{~mm}$ $\mathrm{SL}$, aquarium specimen, Argentina.

\section{Results}

The utricle of all loricariid species investigated in this study is thin-walled and translucent, while the walls of the lagena and saccule are thicker and opaque. The otoliths of loricariids meet the general pattern of teleost otoliths. They are flattened with a smooth dorsal face without relevant morphological characters and a ventral face that holds the main morphological characters. The lapillus is located on the prootic bone with the ventral face orientated towards the bone, while the sagitta and asteriscus are situated at the base of the skull on the basioccipital bone. Sagitta and asteriscus are usually found close together. The face with morphological characters of the asteriscus is oriented towards the center axis of the skull; whereas the sagitta is oriented with the tapered extreme towards the anterior region of the skull (Fig. 1). 


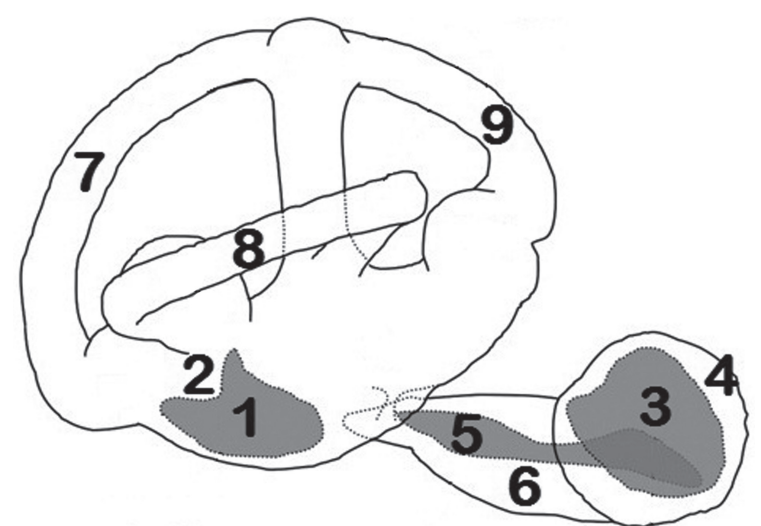

Fig. 1. General structure of the inner ear of a siluriform. 1, Lapillus; 2, Utricle; 3, Asteriscus; 4, Lagena; 5, Sagitta; 6. Saccule; 7, antero-vertical canal; 8, horizontal canal; 9, posterior-vertical canal.

We noted that lapillus otoliths are ovoid or oval, while asteriscus otoliths are piriform or auricular. Unlike the asteriscus, the lapillus is robust and has a characteristic central elevation, the mond, and a deep depression, the sulcus, that delimits one of the edges of the elevation. The sulcus often continues into a secondary, smaller and shallower depression, the sulcus minor (Fig. 2a).

The asteriscus shows a broad, almost straight depression in its central region, the fossa acustica, surrounded by an elevation, the crista, which is followed by a narrow depression called canaliculum. At the anterior edge of the astericus we observed an angular recess, called excisura. The excisura defines an upper and a lower projection, called rostrum and antirrostrum, respectively (Fig. 2b).
The sagitta is the most fragile of the three otoliths. Its shape is clavate, with a tapered posterior region and a flared anterior one. In the latter, central elevations are observed; the dorsal wings are continuous with lateral expansions named basal wings. The degree of projection of these expansions is what determines the shape of the anterior region, which can be rectangular, fusiform, ovoid or rhomboid. The depression in the sagitta, the fissura, has a sinuous path and is delimited by the dorsal wings. At the junction between the anterior and posterior regions, an angle greater than ninety degrees is formed. This determines that the otolith is not flat (Fig 2c).

Hypoptopomatinae. Otocinclus vittatus Regan, 1904. Lapillus: Oval otolith, elongated in its supero-inferior axis with smooth edges. It has a short and wide sulcus that is continuous on a sulcus minor completely surrounding the mond. The latter have a rhomboid-shape and is located in a central position. The mond shows a projection directed towards the lower edge (Fig. 3a). Asteriscus: Auricular otolith, elongated in its supero-inferior axis, its edges are smooth. In the leading edge the excisura is not observed. The fossa acustica has a central position; it is wide and long, exceeding the average axis otolith. The crista and canaliculum are narrow and both of them of full path (Fig. 3b). Sagitta: Claviform otolith with the anterior region rectangular, the basal wings poorly developed and one of them forming a well-developed process. Only one of the dorsal wings is clearly visible and occupies the central region of the otolith, so that the fissura is displaced laterally, describing a sinuous path (Fig. 3c).
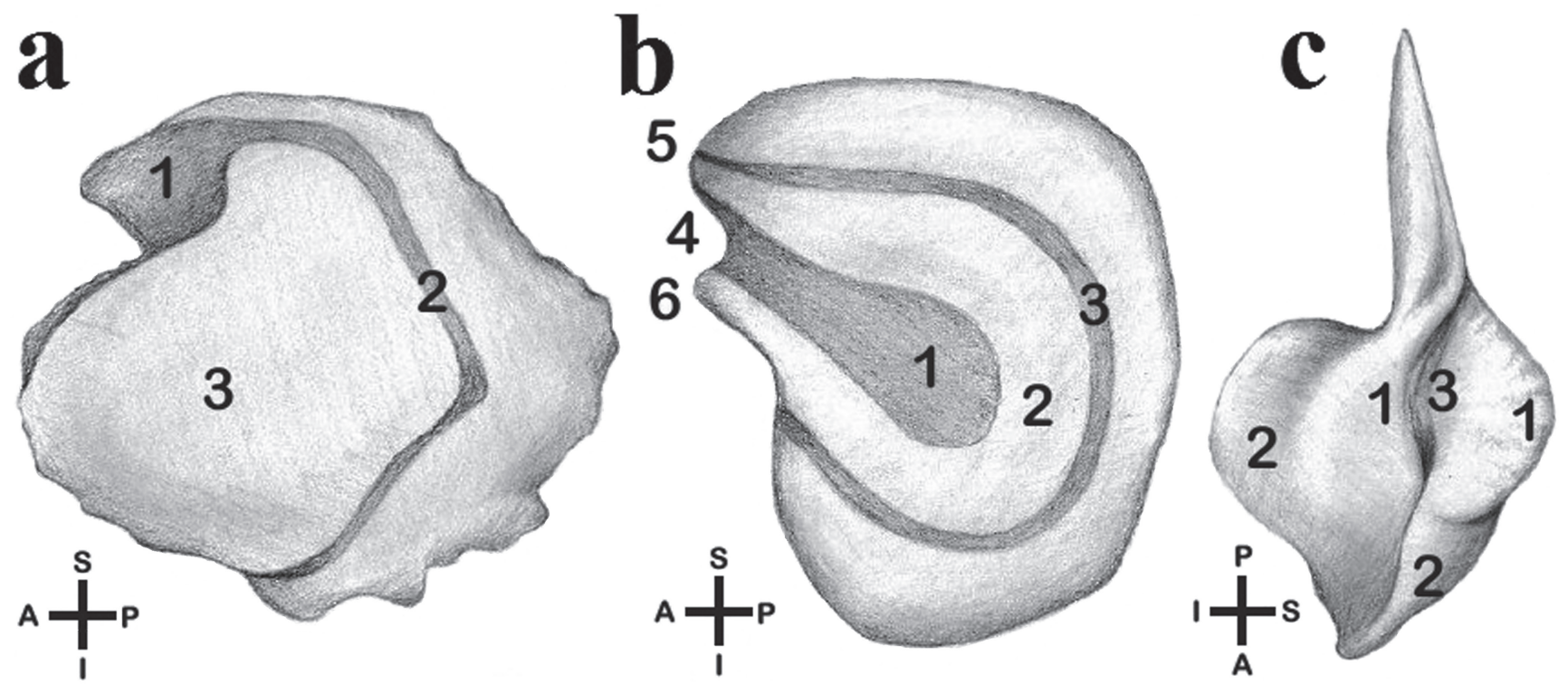

Fig. 2. General structure and morphological features of the three otoliths (a) Lapillus. 1, sulcus; $\mathbf{2}$, sulcus minor; $\mathbf{3}$, mond. (b) Asteriscus. 1, fossa acustica; 2, crista; 3, canalículum; 4, excisura; $\mathbf{5}$ rostrum; 6, antirrostrum. (c) Sagitta. 1, dorsal wings; 2, basal wings; 3, fissura. In all the cases A, anterior region; $\mathbf{P}$, posterior region; $\mathbf{S}$, superior region; I, inferior region. 

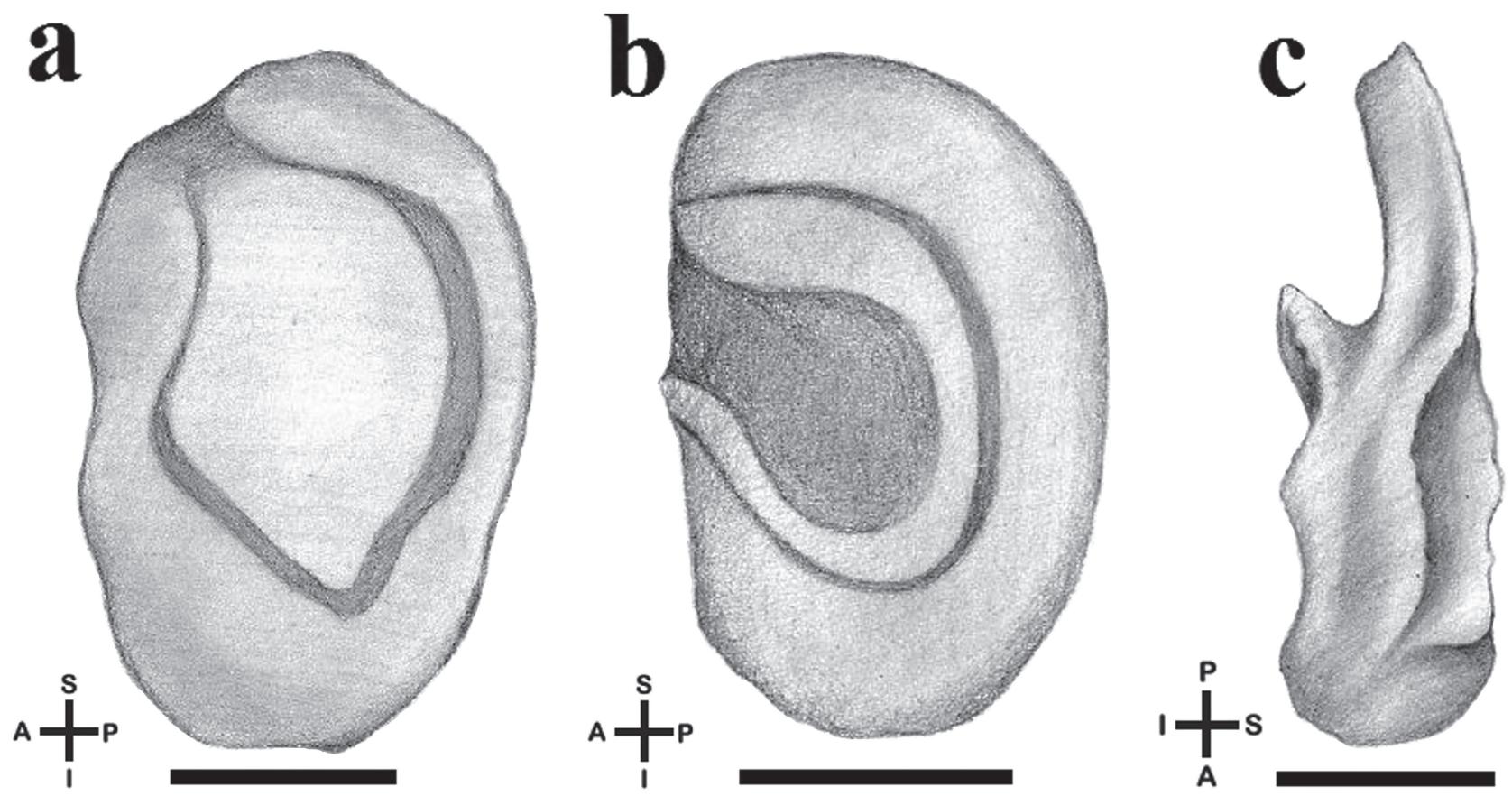

Fig. 3. Right serie of otoliths of Otocinclus vittatus (a) Lapillus, Scale bar $=200 \mu \mathrm{m}$; (b) Asteriscus, Scale bar $=200 \mu \mathrm{m}$; (c) Sagitta, Scale bar $=200 \mu \mathrm{m}$.

Hypoptopoma inexspectatum (Holmberg, 1893). Lapillus: Elongated otolith in its supero-inferior axis, ovoidshaped, and with smooth edges. It has a wide and long sulcus and a large and complete sulcus minor that surrounds the mond. The mond is large, central, and more or less square-shaped, with a projection toward the upper end of the otolith separating the sulcus from the sulcus minor (Fig. 4a). Asteriscus: Elongated otolith in its supero-inferior axis, auricular-shaped, and with smooth edges. The excisura is not observed. The fossa acustica, of central position, is wide and markedly exceeds the average otolith axis, approaching the trailing edge. The crista is narrow and so is the canaliculum and it is of full path (Fig. 4b). Sagitta: Claviform otolith. It has a fusiform anterior region. The basal wings are more developed. The only dorsal wing remains undeveloped, and limits with a shallow, wide and winding fissura (Fig. 4c).
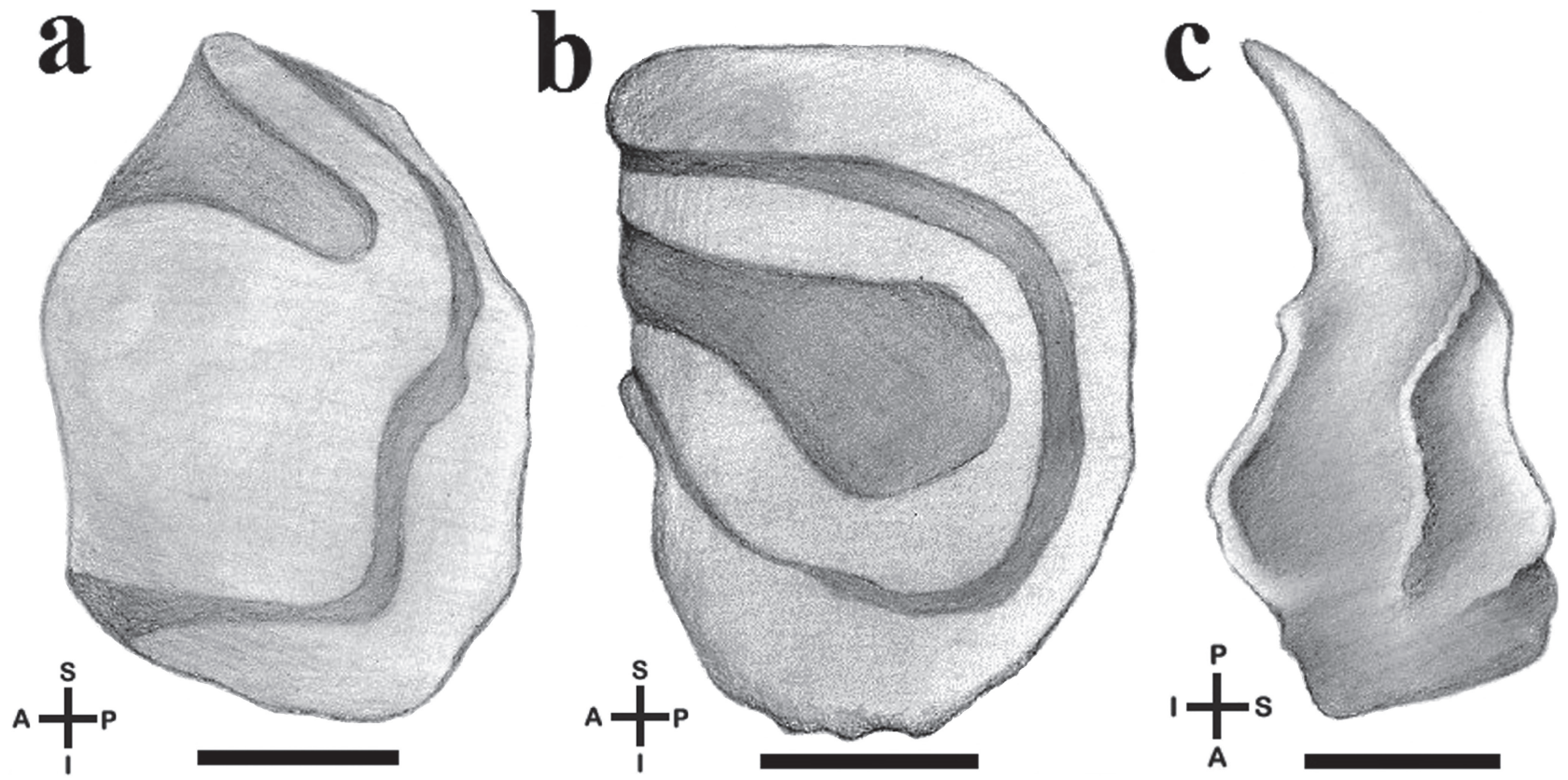

Fig. 4. Right serie of otoliths of Hypoptopoma inexpectatum (a) Lapillus, Scale bar $=200 \mu \mathrm{m}$; (b) Asteriscus, Scale bar $=200$ $\mu \mathrm{m}$; (c) Sagitta, Scale bar $=200 \mu \mathrm{m}$. 
Loricariinae. Rineloricaria catamarcensis (Berg, 1895). Lapillus: Elongated otolith in its supero-inferior axis, ovoidshaped with scalloped edges. It has a wide sulcus of which its length exceeds the median axis of the otolith, reaching almost to the trailing edge. It presents a well-defined sulcus minor completely surrounding the mond. The latter is more or less rectangular, of central position, reaching the front edge without actually going over it. (Fig. 5a). Asteriscus: Pyriform otolith with smooth edges. In the front edge defining a small excisura a rostrum and antirrostrum are observed. The fossa acustica occupies a central position; it is narrow and its length exceeds the median axis of the otolith approaching the trailing edge. The crista is broad and the canaliculum is narrow (Fig. $5 b)$. Sagitta: Claviform otolith. Its anterior region is ovoid due to the further development of basal wings. The dorsal wings appear as robust expansions accompanying the wide fissura that has an almost straight path (Fig. 5c).

Rineloricaria sp. Lapillus: Elongated otolith in its superoinferior shaft, ovoid-shaped with smooth to slightly wavy edges. The sulcus is wide and its length exceeds the median axis of the otolith. It has a wide sulcus minor, which completely surrounds the mond. The latter is more or less rounded and its position is slightly beyond the leading edge (Fig. 6a). Asteriscus: Pyriform otolith with smooth edges. At the front edge there is a small excisura that defines the rostrum and antirrostrum. The fossa acustica occupies a central position. It is wide and its length exceeds the median axis of the otolith. The crista is wide and the canaliculum is narrow, both of full path, that is to say, they are not interrupted (Fig. 6b). Sagitta: Claviform otolith. Its anterior region is ovoid with great development of the basal wings; the only noticeable dorsal wing is displaced laterally and accompanies the fissura in its winding path (Fig. 6c).
Paraloricaria vetula (Valenciennes, 1835). Lapillus: Rounded otolith, with smooth edges. The sulcus is wide and short, not reaching the middle axis of the otolith. It presents a sulcus minor that is not that obvious. The mond is oval, of central position, and slightly exceeds the anterior edge of the otolith (Fig. 7a). Asteriscus: Elongated otolith in its superoinferior axis; its general shape is piriform with wavy edges. In the front edge there is an excisura that defines an obvious rostrum and antirrostrun. The fossa acustica is wide and long, exceeding the median axis of the otolith. It has a broad crista and a narrow canaliculum, both of full path (Fig. 7b). Sagitta: Claviform otolith; its anterior region is rhomboid due to further expansion of the basal wings. The dorsal wings are developed; one of them occupies the central region of the otolith and the other is notoriously expanded laterally. Its shape is round. The fissura is wide, displaced laterally and describing a little winding path (Fig. 7c).

Rineloricaria steinbachi (Regan, 1906). Lapillus: Elongated otolith in its supero-inferior axis, oval-shaped, and with smooth to wavy edges. The sulcus has a width and length that exceed the median axis of the otolith. The sulcus minor is developed. The mond is rounded, of central position, and not reaching the anterior edge (Fig. 8a). Asteriscus: Elongated otolith in its supero-inferior axis, piriform, and with smooth edges. The fossa acustica is wide, straight and exceeds the median axis of the otolith. The crista is broad and the canaliculum is narrow, both of full path. The slightly angled excisura defines a rounded rostrum and a little conspicuous antirrostrum (Fig. 8b). Sagitta: Claviform otolith, with an ovoid anterior region. One of the dorsal wings is highly developed; the other dorsal wing is inconspicuous and defines a shallow fissura with winding path (Fig. 8c).
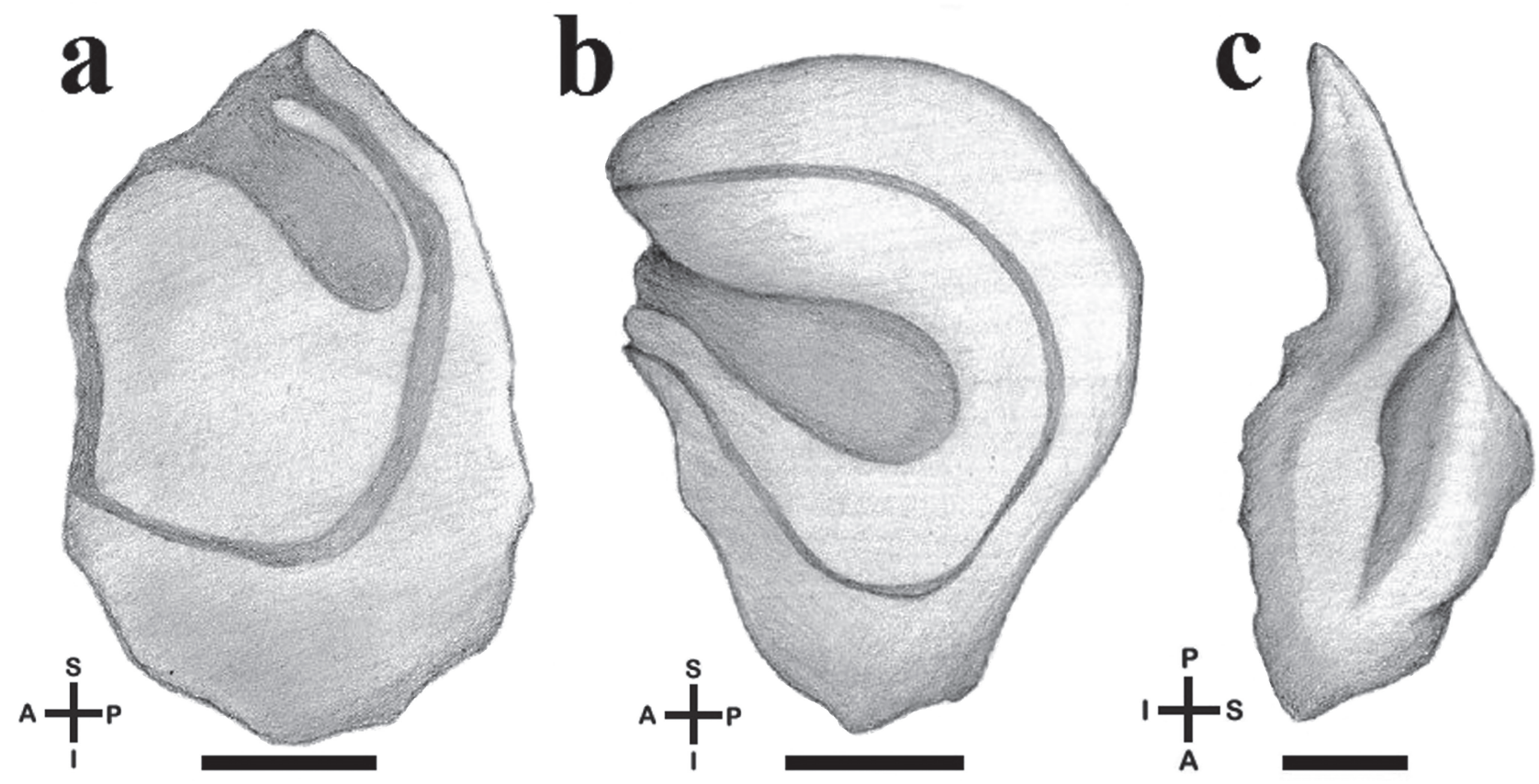

Fig. 5. Right serie of otoliths of Rineloricaria catamarcensis (a) Lapillus, Scale bar $=200 \mu \mathrm{m}$; (b) Asteriscus, Scale bar $=200$ $\mu \mathrm{m}$; (c) Sagitta, Scale bar $=200 \mu \mathrm{m}$. 

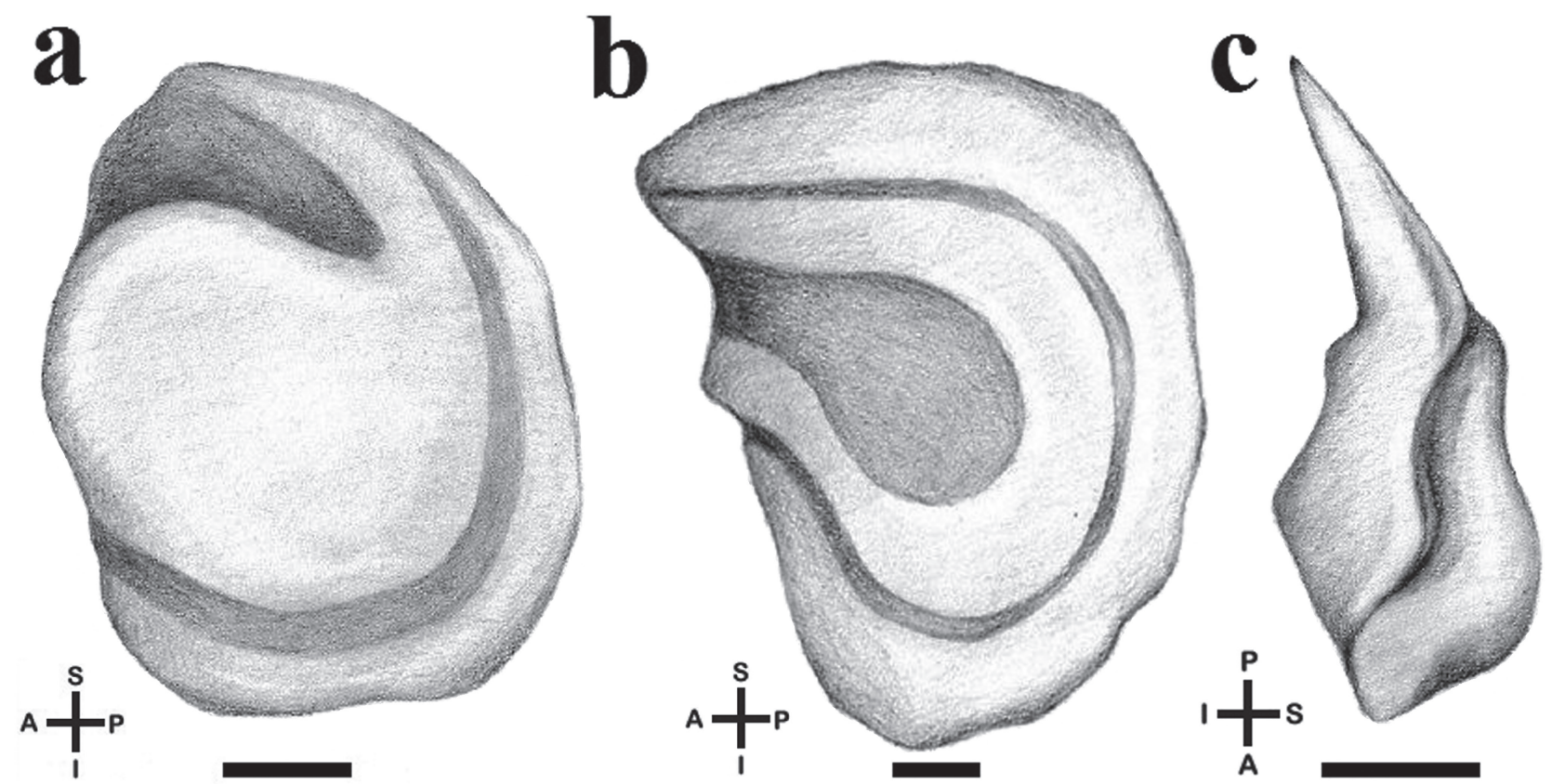

Fig. 6. Right serie of otoliths of Rineloricaria sp. (a) Lapillus, Scale bar $=200 \mu \mathrm{m}$; (b) Asteriscus, Scale bar $=200 \mu \mathrm{m}$; (c) Sagitta, Scale bar $=200 \mu \mathrm{m}$.

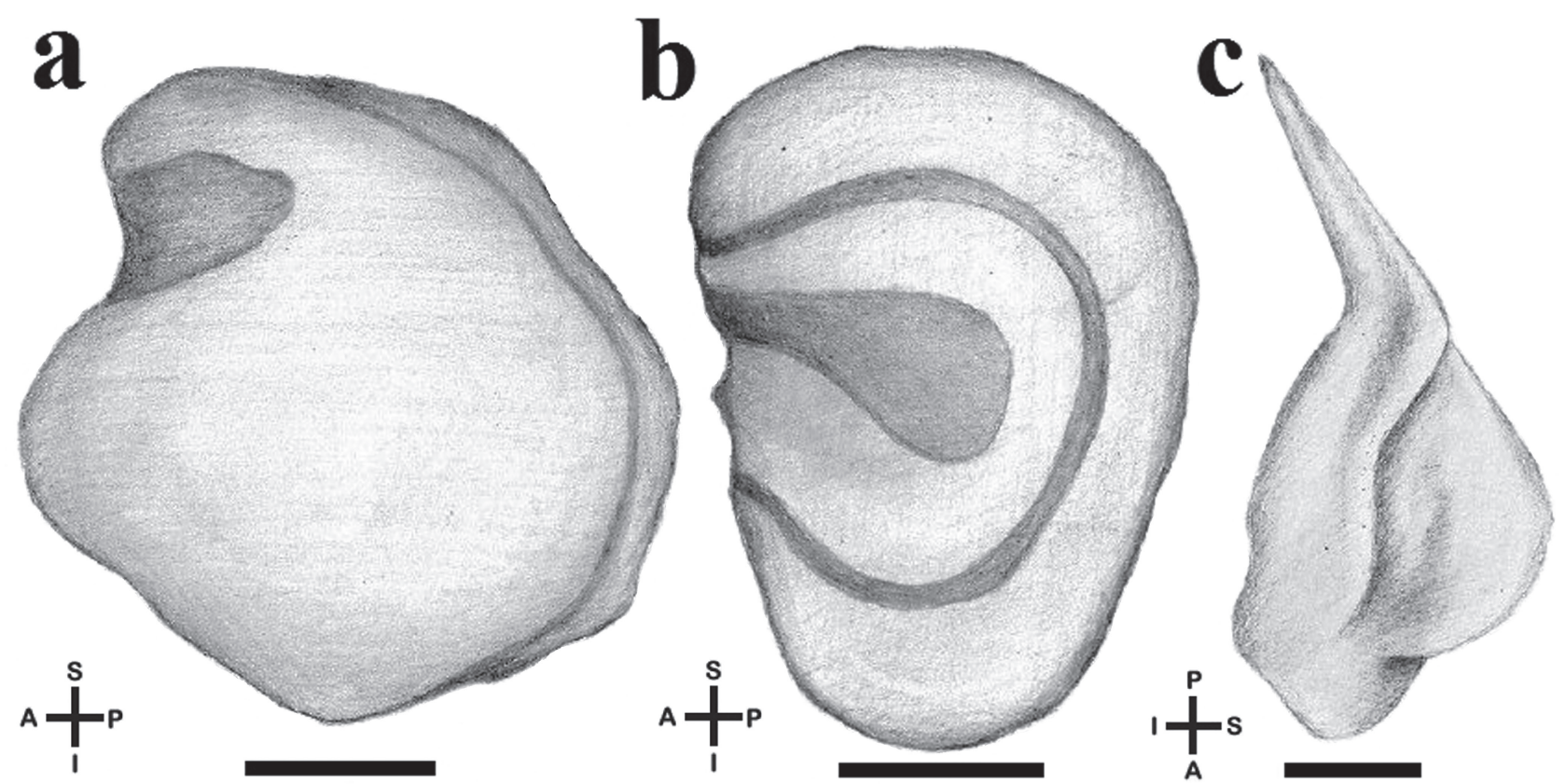

Fig. 7. Right serie of otoliths of Paraloricaria vetula (a) Lapillus, Scale bar $=500 \mu \mathrm{m}$; (b) Asteriscus, Scale bar $=500 \mu \mathrm{m}$; (c) Sagitta, Scale bar $=500 \mu \mathrm{m}$.

Hypostominae. Hypostomus paranensis Weyenbergh, 1877. Lapillus: Elongated and oval otolith in its antero-posterior axis, with irregular edges. It presents a short and narrow sulcus, which continues with a sulcus minor that surrounds the mond. The latter notoriously exceeds the anterior edge; it is roughly polyhedral-shaped, forming a projection that is oriented to the rear edge (Fig. 9a). Asteriscus: Elongated otolith in its supero-inferior axis, oval to rectangular-shaped, and with smooth edges. It presents a marked excisura defining an acute antirrostrum and a round, small rostrum. The fossa acustica is wide and long; it exceeds the median axis of the otolith and descends on its way to the bottom edge. The crista surrounding the fossa acustica is narrow, while the canaliculum is wide and it does not completely surround the crista (Fig. 9b). Sagitta: Claviform otolith, with its anterior region markedly ovoid. It presents robust and well-developed basal wings and the only dorsal wing is not evident. The fissura is narrow, sinuous, and is laterally displaced (Fig. 9c). 

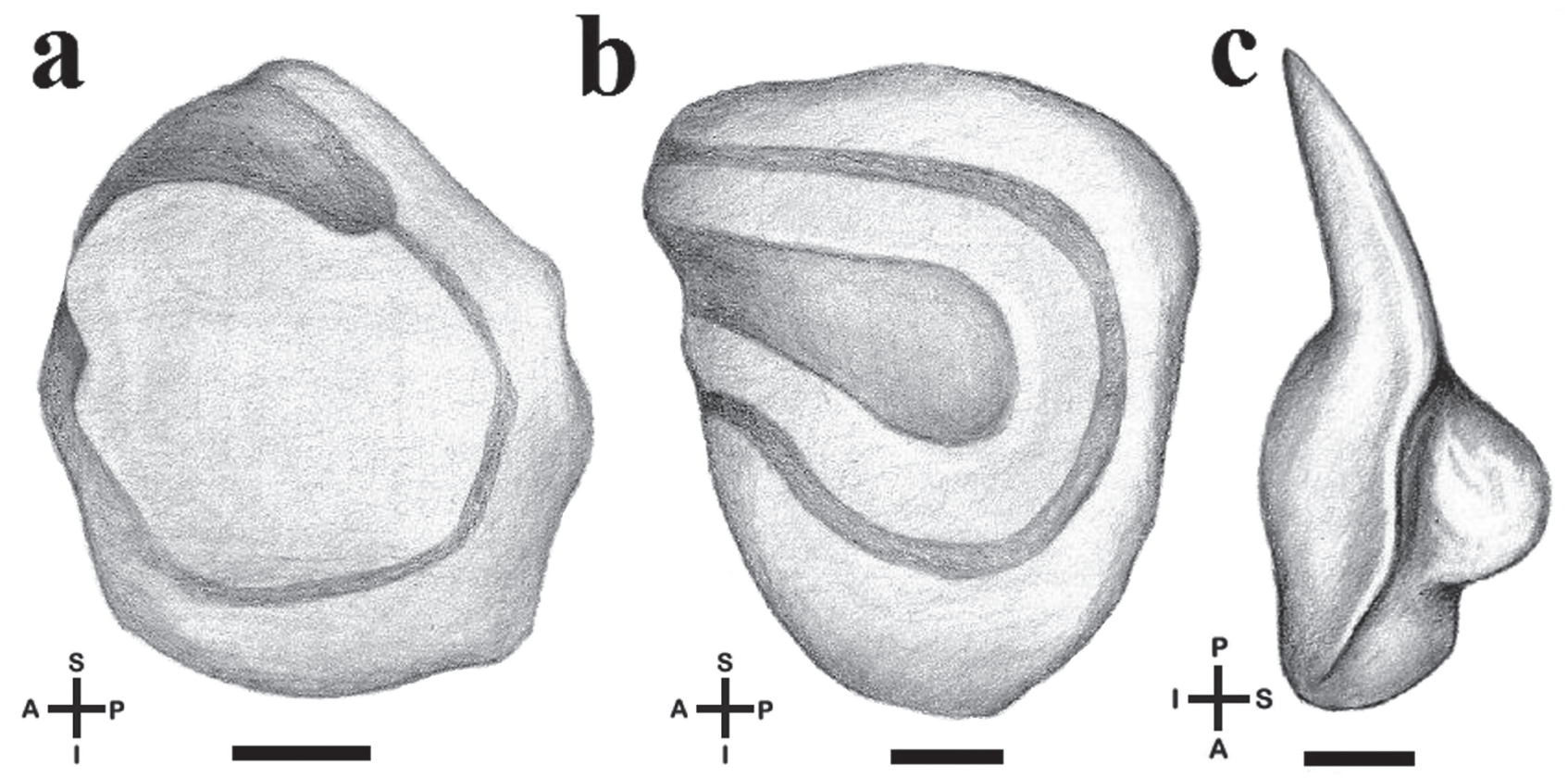

Fig. 8. Right serie of otoliths of Rineloricaria steinbachi (a) Lapillus, Scale bar $=100 \mu \mathrm{m}$; (b) Asteriscus, Scale bar $=100$ $\mu \mathrm{m}$; (c) Sagitta, Scale bar $=100 \mu \mathrm{m}$.
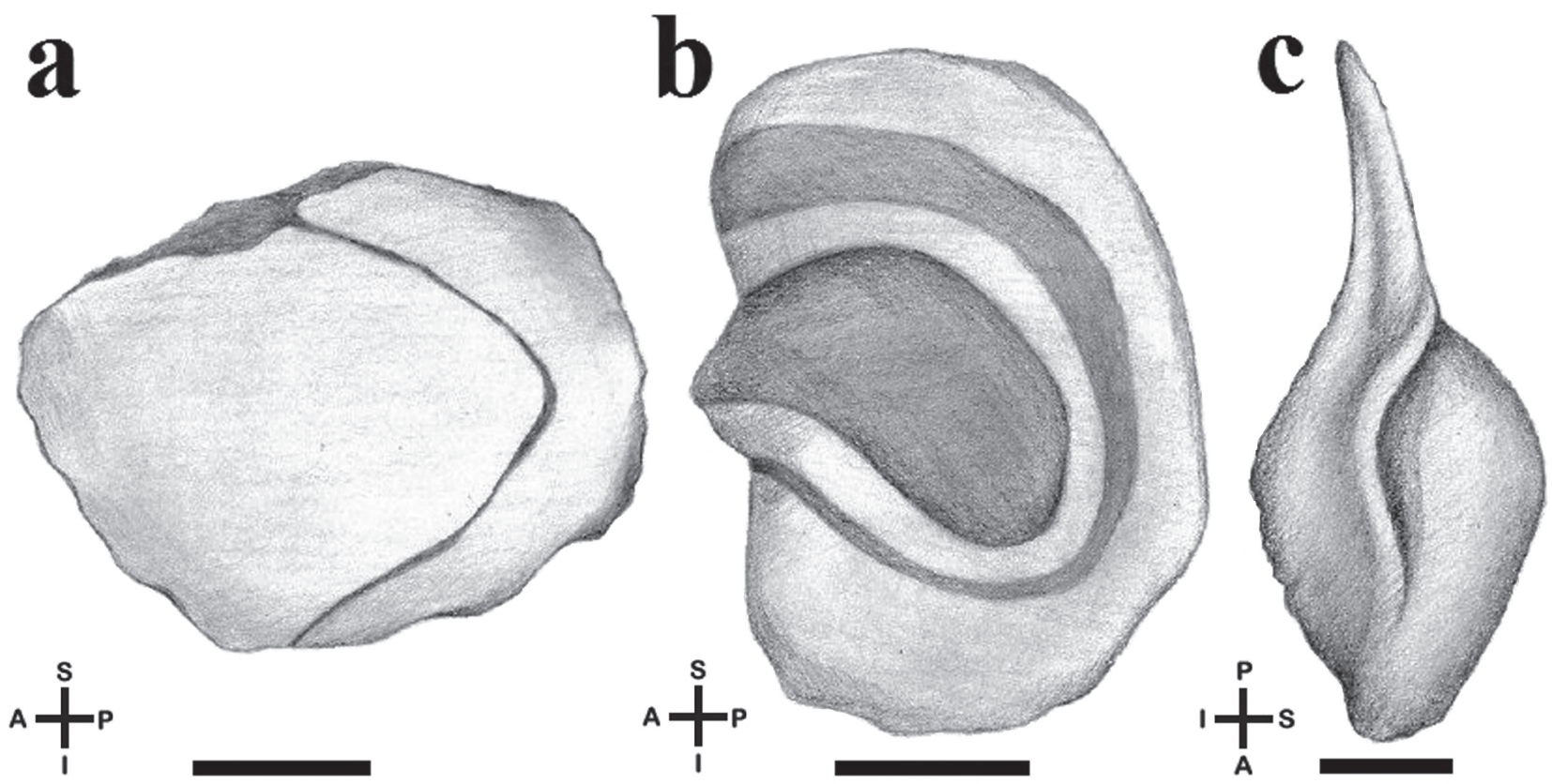

Fig. 9. Right serie of Hypostomus paranensis otoliths of (a) Lapillus, Scale bar $=200 \mu \mathrm{m}$; (b) Asteriscus, Scale bar $=200$ $\mu \mathrm{m}$; (c) Sagitta, Scale bar $=200 \mu \mathrm{m}$.

Hypostomus commersoni Valenciennes, 1836. Lapillus: Elongated otolith in its antero-posterior axis, generally oval, with its edges being smooth to lobed, especially at the trailing edge. It presents a short and wide sulcus; the sulcus minor is not so evident and surrounds the mond. The latter is roughly polyhedral-shaped with a projection directed to the rear edge. The mond is shifted laterally well beyond the leading edge (Fig. 10a). Asteriscus: Elongated otolith in its supero-inferior axis, piriform-shaped, and winding edges. In its leading edge it has an excisura defining a rostrum and antirrostrum that are inconspicuous. The fossa acustica occupies a central position. It is wide and long, and exceeds the median axis of the otolith. The crista is wide and the canaliculum is evident, both of full path (Fig. 10b). Sagitta: Claviform otolith with its anterior region ovoid. With well-developed basal wings with similar development. Only one of the dorsal wings is evident, which is robust and occupies a central position. The fissura is narrow and is located next to the dorsal wing (Fig. 10c). 

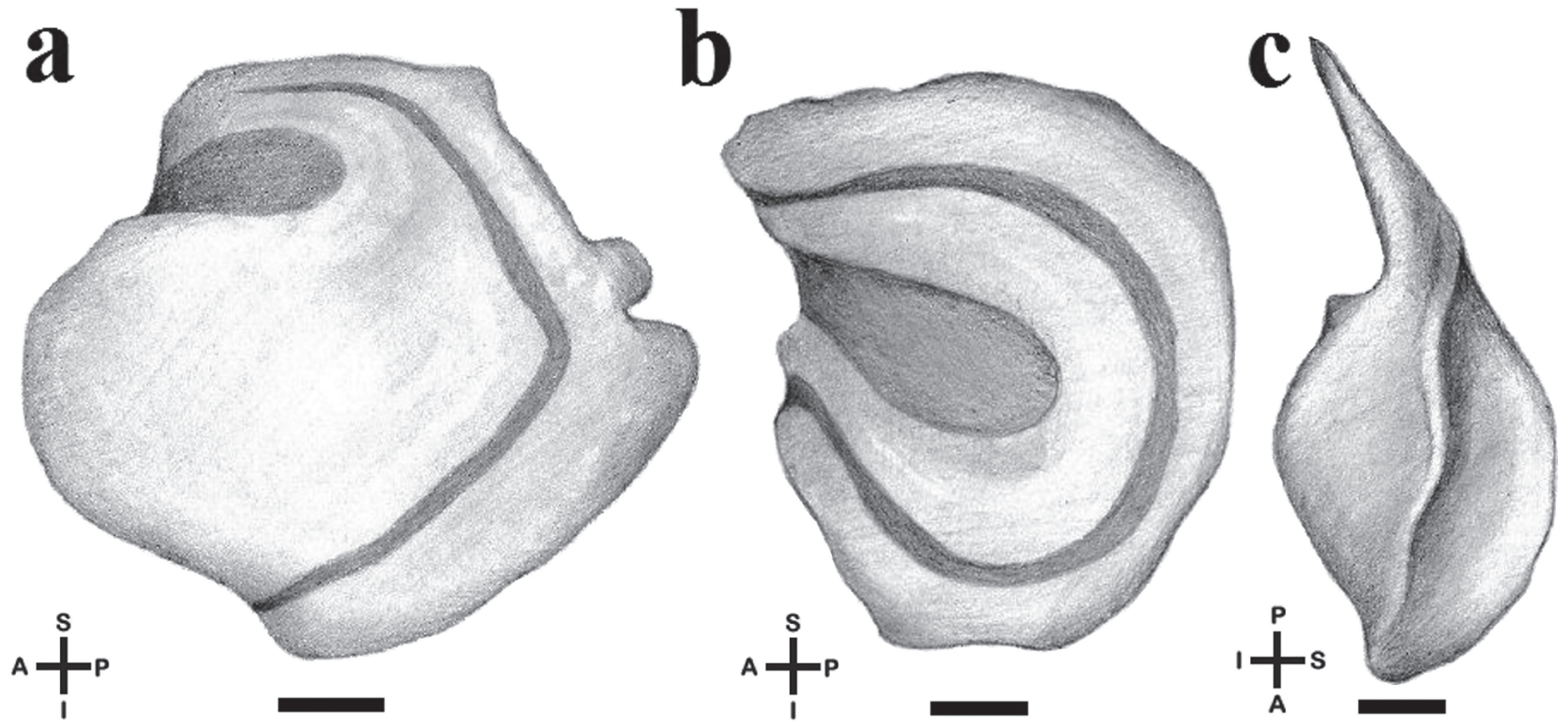

Fig. 10. Right serie of otoliths of Hypostomus commersoni (a) Lapillus, Scale bar = $\mu \mathrm{m}$; (b) Asteriscus, Scale bar = $200 \mu$ m; (c) Sagitta, Scale bar $=200 \mu \mathrm{m}$.

Pterygoplichthys anisitsi Eigenmann \& Kennedy, 1903. Lapillus: Elongated otolith in its antero-posterior axis with irregular wavy lower edges. The sulcus is short, wide and it continues with the sulcus minor to surround the mond. The latter is large, prominent, occupying much of the surface of the otolith. One of the edges is circular and well beyond the anterior edge of the otolith, while the opposite is straight (Fig. 11a). Asteriscus: Elongated otolith in its superoinferior axis, auricular-shaped and with smooth edges. It has a small excisura that defines the rostrum and antirrostrum of almost similar development. The fossa acustica is wide and long, exceeding the median axis of the otolith, ending near the trailing edge. The crista and the canaliculum are wide and of full path (Fig. 11b). Sagitta: Claviform otolith. Its anterior region is rhomboid and the basal wings are strong and well developed. The single dorsal wing rises gently and the fissura occupies a central position, being wide and of winding path (Fig. 11c).
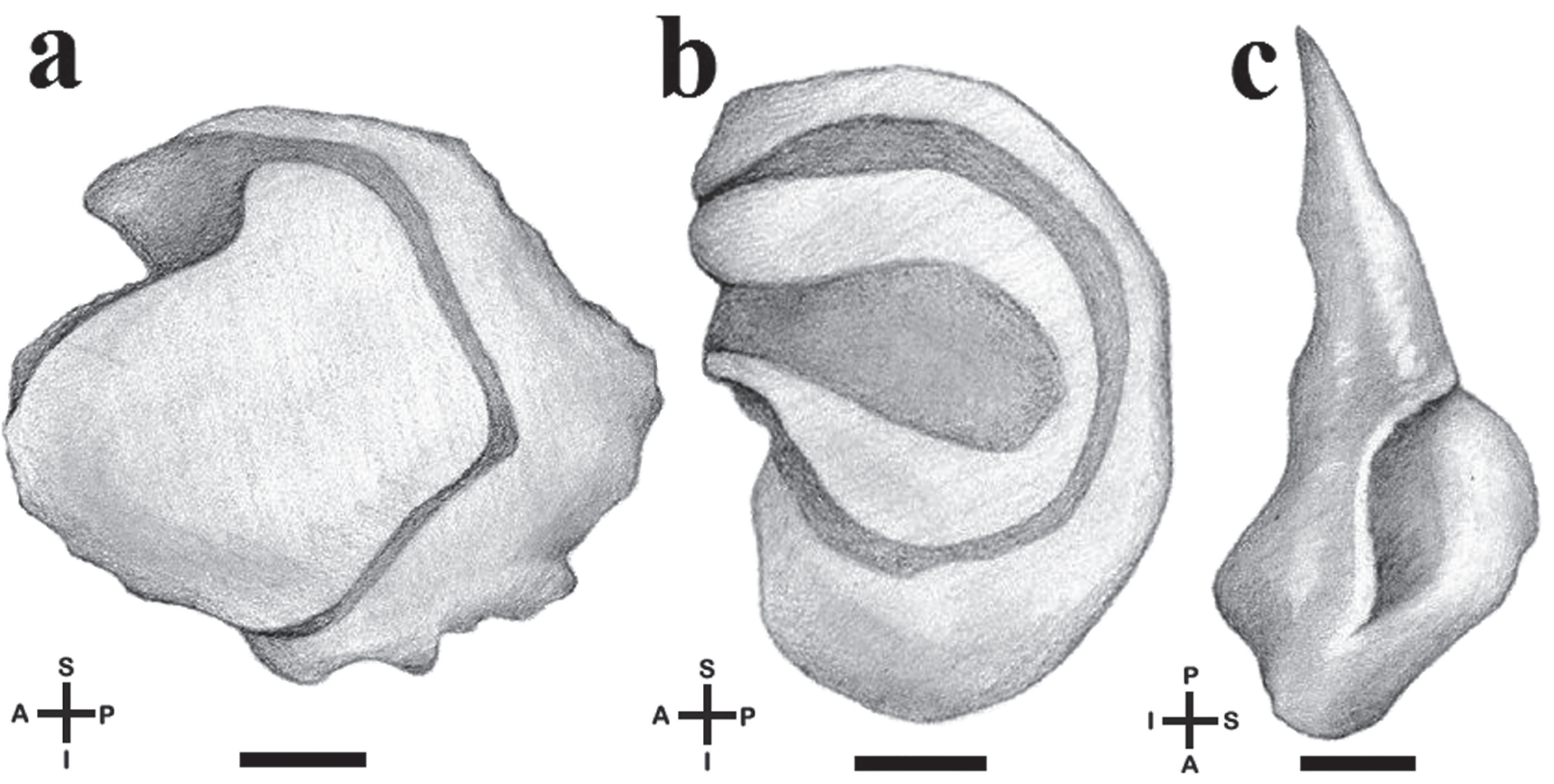

Fig. 11. Right serie of otoliths of Pterygoplichthys anisitsi (a) Lapillus, Scale bar $=500 \mu \mathrm{m}$; (b) Asteriscus, Scale bar $=500$ $\mu \mathrm{m}$; (c) Sagitta, Scale bar $=500 \mu \mathrm{m}$. 
Ancistrinae. Ancistrus cirrhosus (Valenciennes, 1836). Lapillus: Elongated otolith in its antero-posterior axis, ovalshaped, and with smooth edges. The sulcus is short and continues in an apparent sulcus minor that surrounds the mond. The mond occupies a central position; its anterior edge is rounded and exceeds the edge of the otolith, while the opposite edge forms a tapered projection which approaches the posterior edge of the otolith (Fig. 12a). Asteriscus: Elongated otolith in its supero-inferior axis, with pyriform aspect and smooth edges. In shows a slightly angled excisura that fails to define rostrum and antirrostrum in its anterior edge. The fossa acustica is wide; it occupies a central position and exceeds the median axis of the otolith. The crista is broad and is surrounded by the canaliculum, the latter is evident and both are of full path (Fig. 12b). Sagitta: Claviform otolith; its anterior region is markedly rhomboid due to the highly developed basal wings. The dorsal wings are evident, one occupies a central position and the other spreads like a fan. The fissura bounded by the dorsal wings is in the center of the otolith describing a small winding path (Fig. 12c).
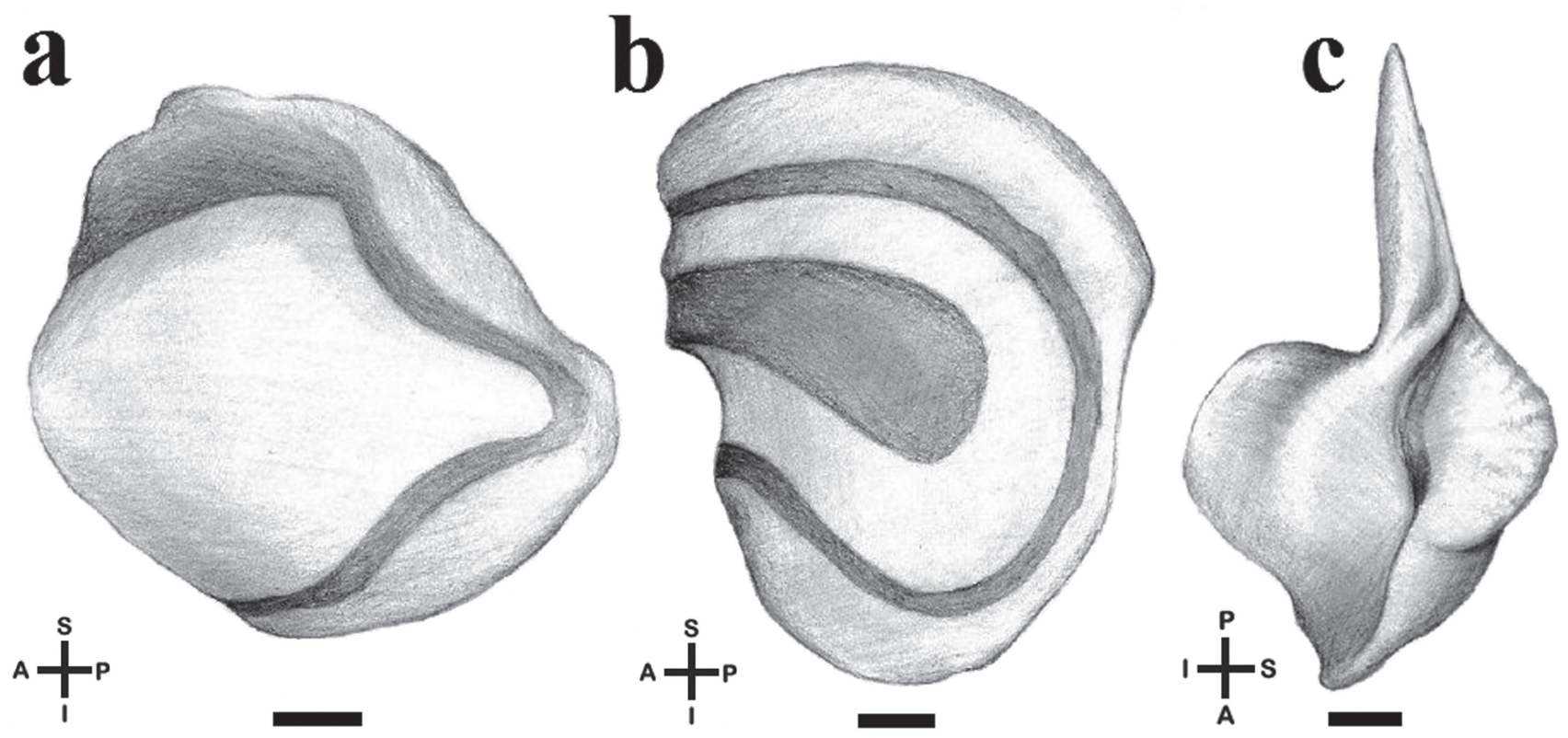

Fig. 12. Right serie of otoliths of Ancistrus cirrhosus (a) Lapillus, Scale bar $=100 \mu \mathrm{m}$; (b) Asteriscus, Scale bar $=100 \mu \mathrm{m}$; (c) Sagitta, Scale bar $=100 \mu \mathrm{m}$.

Ancistrus sp. Lapillus: Elongated otolith in its anteroposterior axis, oval-shaped, and with smooth edges. The sulcus is short and wide. The sulcus minor is evident and completely surrounds the mond. The mond is oval and well beyond the anterior edge (Fig. 13a). Asteriscus: Elongated otolith in its supero-inferior axis, piriform-shaped, and with winding edges. It shows an angled excisura defining a rostrum and antirrostrum. The fossa acustica is less wide. It is long, and exceeds the median axis of the otolith. The crista is broad and is surrounded by the canaliculum, the latter is evident and both are of full path (Fig. 13b). Sagitta: Claviform otolith. Its anterior region is oval due to less developed basal wings. One of the dorsal wings occupies a central position. The fissura is marked and deep describing a winding path accompanying the dorsal wing (Fig. 13c).

\section{Discussion}

There are few studies characterizing otoliths of freshwater fishes. In the case of siluriforms, the otoliths are known by the contributions of a few authors. For example, Adams (1940), Tilak (1963) and Martínez, Gonzo (1991).
The morphology of major structures for each of the three otoliths is very characteristic and we can effectively assign certain morphological characters to a particular species. We were able to confirm the morphologies of the otoliths of Hypostomus paranensis and Hypostomus commersoni previously described by Martínez, Gonzo (1991), and Fuchs, Volpedo (2009).

Each of the three otoliths of Loricariidae presents a characteristic trough: The sulcus (superior position of the lapillus), the fossa acustica (central position of the asteriscus) and the fissura (lateral position of the sagitta). At present the otoliths of more than 50 siluriforms species are known (e.g., Adams, 1940; Tilak, 1963; Martínez, Gonzo, 1991; Fuchs, Volpedo, 2009), and the loricariid otoliths studied here respond to the general pattern of siluriforms. However, they show morphological characteristics that could distinguish the family within the order: robust lapillae with prominent mond, flattened asteriscae of auricular shape and very characteristic sagittae of clavate shape, with winged expansions that define its form (Martínez, Gonzo, 1991).

We agree with Assis (2005), who proposed two morphological patterns for the lapillus of teleost: (1) 

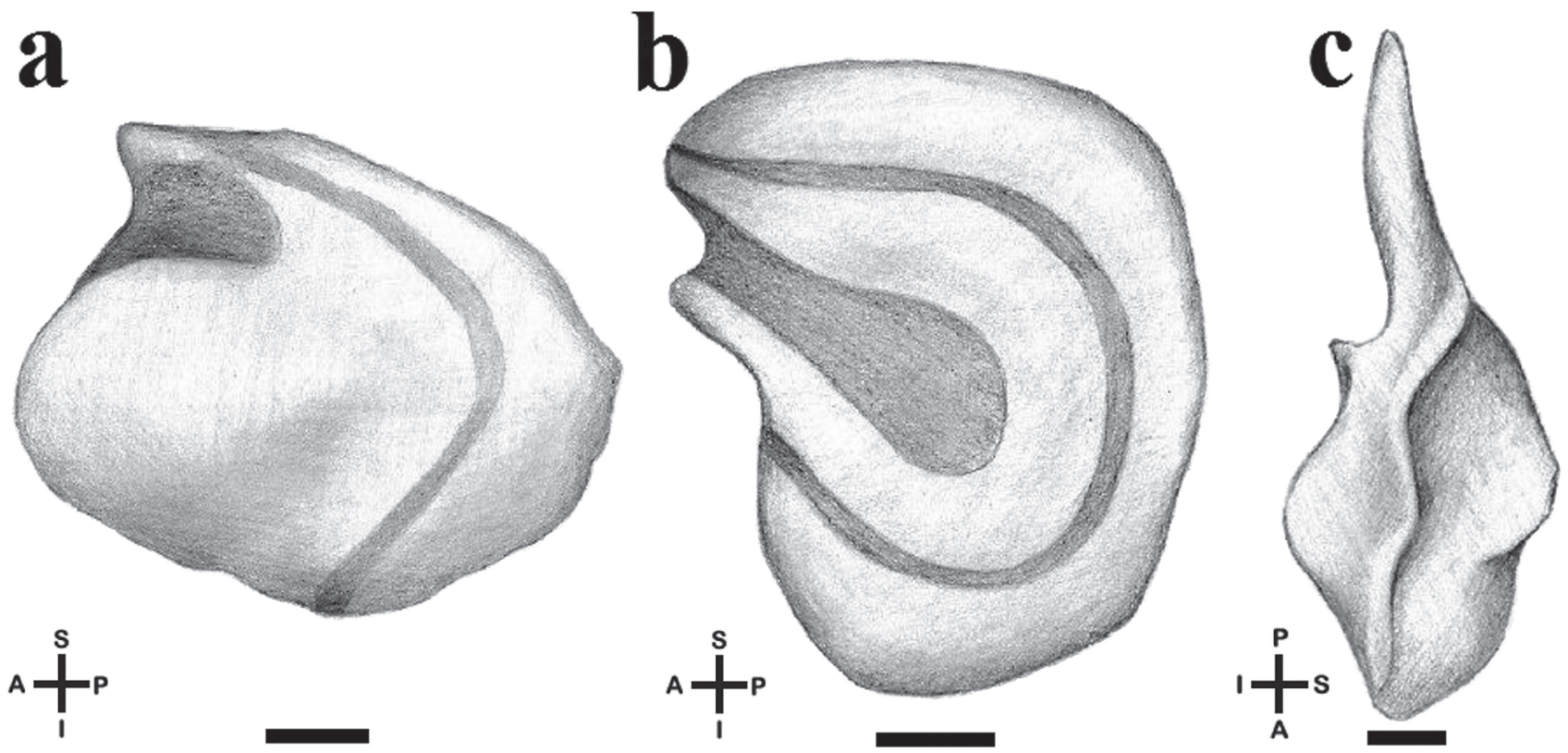

Fig. 13. Right serie of otoliths of Ancistrus sp. (a) Lapillus, Scale bar $=200 \mu \mathrm{m}$; (b) Asteriscus, Scale bar $=200 \mu \mathrm{m}$; (c) Sagitta, Scale bar $=200 \mu \mathrm{m}$.

clupeiform type: highly modified, of tetrahedrical shape, slender with a mond or hump, which is little prominent; and (2) the non-clupeiform type: never tetrahedrical, robust, with strong development of the mond. The lapillus analyzed in the present study correspond to the non-clupeiform type, being robust with prominent mond. Furthermore, we suggest a subdivision of the non-clupeiform type into two morphological patterns: (1) an ovoid model, in which the lapillae are elongated in its supero-inferior axis and the mond hardly exceed the anterior edge of the otolith and (2), an oval model, where the lapillae are elongated in their antero-posterior axis and the mond always exceeds the anterior edge in an obvious way. The studied species of the Hipoptopomatinae and Loricariinae display the ovoid pattern of the lapillae, while the studied species of the Hypostominae and Ancistrinae have the oval pattern. The patterns proposed here could be diagnostic of certain subfamilies. The descriptions of Martínez, Gonzo (1991) and Fuchs, Volpedo (2009) of lapillus of Loricaria simillima Regan 1904 and Loricariichthys anus (Valenciennes 1835) (Loricariinae) fit into the ovoid model proposed herein.

The asteriscus of teleosts may appear in several different forms. Assis (2003) proposed three morphological types of asteriscus, considering, among other characters, shape, orientation, and position of the fossa acustica. He described the vertical type present in Elopomorpha, Clupeomorpha, Scopelomorpha, Protacanthopterygii, and Acanthopterygii; the horizontal type in the Paracanthopterygii; and the gyro type in Otophysi (Cypriniformes, Characiformes, Siluriformes and, Gymnotiformes). In the gyro type, the greatest lobe and the crista completely surround the fossa acustica describing a circumference of nearly 360 degrees and positioning the depression in the center of the otolith. The morphology of the asteriscae of the loricariids investigated in the present study responded to the gyro type. Nonetheless, we point out some peculiarities that call for further investigation, e.g. corroborate the presence of elongated supero-inferior shapes in a greater number of species of the family. In the studied species this otolith presents the upper and lower halves of equal size, with generally smooth edges, a long, descending fossa acustica, usually surrounded by the crista. The excisura may be present, but is usually poorly developed; hence a clear rostrum and antirrostrum cannot be defined. We found that the asteriscus in the studied eleven species show marked differences useful perhaps for species identification. However, their morphological characters are insufficient to differentiate subfamilies. Hence we were unable to establish pattern that could offer a characterization of the subfamilies.

Only three studies have investigated the sagitta of siluriforms (Adams, 1940; Tilak, 1963; Martínez, Gonzo, 1991). Adams (1940) described the sagitta of siluriforms as highly modified and very different from that in other fish orders. In the studied species, this otolith is fusiform with two pairs of wings, basal and dorsal surrounding the fissura. The only descriptions of sagitta of Loricariidae are the ones by Martínez, Gonzo (1991) for Hypostomus paranensis and Loricaria simillima. In the studied species, the sagitta are highlighted by the clavate appearance, where an enlarged anterior region containing the wings, the fissure, the fragile and tapering posterior region are differentiated. As well as the asteriscus, its morphology varies subtly among the studied species which did not allow us to identify morphological features characterizing subfamilies. We agree with Martínez, Gonzo (1991) 
that some morphological features of the sagittae are characteristic for Loricariidae, as for instance the shape of the basal wings, which are expanded, while in other sagittae the wings are small or reduced.

Our study supports previous findings that the morphological characterization of otoliths is relevant in species identification (e.g., Hernández García, et al., 2004; Tuset et al., 2012).

The fact of having found an apparent morphological pattern makes us suppose that otoliths could show synapomorphic characters. Further studies on the morphology of the three otoliths in more species are needed to confirm whether the otoliths present morphological characters of phylogenetic importance in some groups.

\section{Acknowledgments}

Authors are grateful with people who contributed in different ways to the preparation of this article: Alfredo Alvino for his help with the illustrations; Luis Fernández and Gladys Monasterio for assistance in species identification; Sergio Bogan and Yamila Cardoso for loan of specimens for dissection; and three anonymous reviewers for their useful comments on an earlier version of the manuscript.

\section{References}

Adams LA. Some characteristic otoliths of American ostariophysi. J Morphol. 1940; 66(3):497-527.

Aguirre WE. Allometric growth of the sulcus in Cynoscion spp. (Sciaenidae). J Fish Biol. 2003; 63(5):1341-46.

Albuquerque CQ, Miekeley N, Muelbert JH. Whitemouth croaker, Micropogonias furnieri, trapped in a freshwater coastal lagoon: a natural comparison of freshwater and marine influences on otolith chemistry. Neotrop Ichthyol. 2010; 8(2):311-20.

Assis CA. The lagenar otoliths of teleosts: their morphology and its application in species identification, phylogeny and systematics. J Fish Biol. 2003; 62(6):1268-95.

Assis CA. The utricular otoliths, lapilli, of teleosts: their morphology and relevance for species identification and systematic studies. Sci Mar. 2005; 69(2):259-73.

Campana SE. Chemistry and composition of fish otoliths: pathways, mechanisms and applications. Mar Ecol Prog Ser. 1999; 188(November 3 1999):263-97.

Correia AT, Antunes C, Isidro EJ, Coimbra J. Changes in otolith microstructure and microchemistry during larval development of the European conger eel (Conger conger). Mar Biol. 2003; 142(4):777-89.

Fowler AJ. Validation of annual growth increments in the otoliths of a small, tropical coral reef fish. Mar Ecol Prog Ser. 1990; 64:25-38

Fuchs DV, Volpedo AV. Morfología de lapillus de siluriformes parano-platenses. Biol. Acuát. 2009; 26:97-108.

Hernández García MR, Martínez Pérez JA, Bautista López TA, Reséndiz Rodríguez JM. Descripción morfológica de los otolitos de las familias Engraulidae, Haemulidae y Achiridae del sistema estuarino de Tecolutla, Veracruz. Rev Zool Univ Nac Auton Mex. 2004; 2004(15):7-13.
Ilkyaz AT, Metin G, Kinacigil HT. The use of otolith length and weight measurements in age estimations of three Gobiidae species (Deltentosteus quadrimaculatus, Gobius niger, and Lesueurigobius friesii). Turk J Zool. 2011; 35(6):819-27.

Lombarte A, Palmer M, Matallanas J, Gómez-Zurita J, MoralesNin B. Ecomorphological trends and phylogenetic inertia of otolith sagittae in Nototheniidae. Environ Biol Fishes. 2010; 89(3):607-18.

Martínez V, Gonzo G. Clave de identificación de algunos peces Siluriformes en base al estudio de sus otolitos. Revista de la Asociación de Ciencias Naturales del Litoral. 1991; 22(2):95-118.

Martínez V, Gonzo G. Morfología de los otolitos de Heptapterus mustelinus (Valenciennes 1840) (Pimelodidae), su relación con parámetros dimensionales. Revista de la Asociación de Ciencias Naturales del Litoral. 1988; 19(1):27-37.

Mollo SM. Otolitos de peces de la laguna Chascomús (Provincia de Buenos Aires). Análisis y consideraciones para su identificación en estudios tróficos. Limnobios. 1981;2(4):253-63.

Monteiro LR, Di Beneditto APM, Guillermo LH, Rivera LA. Allometric changes and shape differentiation of sagitta otoliths in sciaenid fishes. Fish Res. 2005; 74(1-3):288-99.

Morales-Nin B. Review of the growth regulation processes of otolith daily increment formation. Fish Res. 2000; 46(13):53-67.

Nolf D, Brzobohatý R. Lower Badenian fish otoliths of the Styrian and Lavanttal basins, with a revision of Weinfurter's type material. Ann Naturhist Mus Wien, Ser. A. 2009; 111:323-56.

Pierce GJ, Boyle PR, Diack JSW. Identification of fish otoliths and bones in faeces and digestive tracts of seals. J Zool. 1991; 224(2):320-28.

Popper AN, Lu Z. Structure-function relationships in fish otolith organs. Fish Res. 2000; 46(1-3):15-25.

Popper AN, Ramcharitar J, Campana SE. Why otoliths? Insights from inner ear physiology and fisheries biology. Mar Freshw Res. 2005; 56:497-504.

Schulz-Mirbach T, Reichenbacher B. Reconstruction of Oligocene and Neogene freshwater fish faunas - an actualistic study on cypriniform otoliths. Acta Palaeontol Pol. 2006; 51(2):283-304.

Tilak R. Studies on the comparative morphology of the otoliths of Indian Siluroids. Zool Anz. 1963; 173:181-201.

Tollit DJ, Steward MJ, Thompson PM, Pierce GJ, Santos MB, Hughes S. Species and size differences in the digestion of otoliths and beaks: implications for estimates of pinniped diet composition. Can J Fish Aquat Sci. 1997; 54(1):105-19.

Tuset VM, Azzurro E, Lombarte, A. Identification of Lessepsian fish species using the sagittal otolith. Sci. Mar. 2012; 76(2):289-99.

Volk EC, Schroder SL, Grimm JJ. Otolith thermal marking. Fish Res. 1999; 43(1-3):205-19.

Volpedo A, Echeverría DD. Ecomorphological patterns of the sagitta in fish on the continental shelf off Argentine. Fish Res. 2003; 600(2-3):551-60.

Volpedo AV, Fuchs DV. Ecomorphological patterns of the lapilli of Paranoplatense Siluriforms (South America). Fish Res. 2010; 102:160-65. 
